\title{
EVALUASI PRAKTIK KERJA INDUSTRI KOMPETENSI KEAHLIAN PEMASARAN SMKN 1 PENGASIH, KULON PROGO
}

\author{
Siti Umi Khayatun Mardiyah \\ Pendidikan Administrasi Perkantoran FE UNY \\ ummikha@uny.ac.id \\ Edy Supriyadi \\ Fakultas Teknik Universitas Negeri Yogyakarta \\ edy_via@yahoo.com
}

\begin{abstract}
Abstrak
Penelitian ini bertujuan untuk mengevaluasi praktik kerja industri (prakerin) Kompetensi Keahlian Pemasaran SMK N 1 Pengasih, Kulon Progo. Jenis penelitian yang digunakan adalah evaluasi dengan pendekatan model CIPP (Context, Input, Process, Product). Sampel penelitian sebanyak 75 siswa, 7 guru, dan 5 instruktur. Penelitian dilakukan di SMK N 1 Pengasih dan dunia usaha/dunia industri (DUDI). Pengumpulan data dengan angket, observasi, wawancara, dan dokumentasi. Analisis data secara deskriptif dengan bantuan seri program SPSS versi 19,0. Validitas instrumen menggunakan validitas konstruk dan isi. Penentuan reliabilitas menggunakan rumus Alpha Cronbach. Hasil penelitian menunjukkan: (1) aspek konteks menurut guru,siswa, dan instruktur termasuk dalam kategori sangat relevan; (2) aspek input menurut guru dan siswa termasuk dalam kategori kurang baik, menurut instruktur masuk dalam kategori baik; (3) aspek proses menurut guru dan instruktur masuk dalam kategori sangat baik, menurut siswa masuk dalam kategori baik; (4) aspek produk menurut guru, siswa dan instruktur masuk dalam kategori sangat baik; 5) secara umum kelemahan pelaksanaan prakerin adalah: kurangnya keterlibatan siswa dan instruktur dalam perencanaan program, kurangnya kontrol sekolah,dan kurangnya kesempatan bagi siswa untuk menguasai kompetensi yang diperoleh dari DUDI;
\end{abstract}

Kata kunc: praktik kerja industri, evaluasi

\section{AN EVALUATION OF THE INDUSTRIAL JOB PRACTICUM PROGRAM IN THE MARKETING EXPERTISE COMPETENCY IN SMK N 1 PENGASIH, KULON PROGO}

\begin{abstract}
This study aims to investigate the evaluation of the industrial job practicum program in the Marketing Expertise Competency in SMK N 1 Pengasih, Kulon Progo. This was an evaluation study employing the CIPP (Context, Input, Process, Product) model. The subjects comprised 75 students, seven supervising teachers, and five field instructors. The study was conducted in SMK $N 1$ Pengasih and the Business and Industrial Sectors as a partner for he industrial job practicum. The data were collected through a questionnaire, observations, interviews, and documentation. The quantitative data were analyzed by means of the descriptive technique using the SPSS Version 19.0 program. The instrument validation employed the construct and content validity through expert judgment. The reliability was assessed using the Cronbach's Alpha formula. The results of the study are as follows. (1) The context aspect is in the very good category according to the teacher, instructor, and student respondents. (2) The input aspect is in the poor category according to the teacher respondents, in the good category according to the instructor respondents, and in the poor category according to the student respondents. (3) The process is in the very very good category according to the teacher and instructor respondents, and in the good category according to the student respondent. (4) The product aspect is in the very good category according to the teacher, instructor, and student respondents. (5) In general, the weaknesses in the implementation of the industrial job practicum include: the lack of the students' and instructors' involvement in the program planning, the lack of the school control, and the lack of opportunity for the students to acquire the competencies from the business and industrial sectors.
\end{abstract}

Keyword: industrial job practicum, evaluation 


\section{PENDAHULUAN}

Sekolah kejuruan bertujuan untuk mencetak lulusan yang siap kerja, terampil, dan berdaya saing. Dengan kata lain, sekolah kejuruan membekali siswanya dengan keterampilan-keterampilan tertentu agar kelak setelah menyelesaikan pendidikan dapat bersaing baik sebagai pekerja di dunia usaha/ dunia industri (DUDI) maupun sebagai wiraswasta.

Pembekalan keterampilan kepada siswa memiliki peran penting dalam upaya peningkatan tenaga terampil di Indonesia. Alasan tenaga kerja terampil sangat penting yaitu: 1) Tenaga kerja terampil memegang peranan penting dalam menentukan tingkat mutu dan biaya produksi; 2) Tenaga kerja terampil sangat dibutuhkan untuk mendukung pertumbuhan industrialisasi suatu negara; 3) Tenaga kerja terampil merupakan faktor keunggulan menghadapi persaingan global; 4) Penerapan teknologi agar berperan menjadi faktor keunggulan tergantung kepada tenaga kerja yang terampil yang menguasai dan mampu mengaplikasikannya; 5) Orang yang memiliki keterampilan memiliki peluang tinggi untuk bekerja dan produktif; serta 6) Semakin banyak warga suatu bangsa yang tidak terampil, semakin tinggi kemungkinan pengangguran yang akan menjadi beban ekonomi Negara (Wardiman Djojonegoro, 1998).

Paradigma pendidikan kejuruan sangat berbeda dengan pendidikan umum. Pendidikan kejuruan (education for earning living) menekankan pada pendidikan yang menyesuaikan dengan permintaan pasar (demand driven). Kebersambungan (link) diantara pengguna lulusan pendidikan dan penyelenggara pendidikan serta kecocokan (match) diantara employee dengan employer menjadi dasar penyelenggaraan dan ukuran keberhasilan pendidikan kejuruan. Keberhasilan penyelenggaraan pendidikan kejuruan dapat dilihat dari tingkat mutu dan relevansi yaitu jumlah penyerapan lulusan dan kesesuaian bidang pekerjaan dengan bidang keahlian yang dipilih dan ditekuninya.

Kebijakan link and match pada awalnya merupakan penjabaran amanat GBHN 1993 dan pada dasarnya berlaku untuk seluruh jenis dan jenjang pendidikan. Menurut Wardiman (1998) kebijakan ini mengandung dua muatan penting, yaitu makna filosofis yang dimaksudkan untuk membarui, menata, dan meluruskan sistem nilai, pola pikir, sikap mental, perilaku, dan kebiasaan para pemikir, perencana, pengelola dan pelaku pendidikan kejuruan itu sendiri, serta kebijakan operasional yang menjadi prinsip dalam penyusunan Kompetensi dan penyelenggaraan pendidikan dan pelatihan kejuruan. Pada pendidikan menengah kejuruan, kebijakan ini telah dioperasionalkan dalam wujud Praktik Kerja Industri (prakerin). Prakerin merupakan bagian dari kompetensi bersama antara SMK dan industri yang dilaksanakan di dunia usaha dan dunia industri (DUDI).

Seiring dengan bergulirnya era globalisasi perdagangan dan investasi yang merupakan era keterbukaan tanpa batas (borderless) khususnya dalam bidang ekonomi, menuntut sumberdaya manusia yang kompeten dan berdaya saing. Untuk menghadapi tantangan era global, sudah tentu diperlukan kemampuan daya saing yang tangguh, dimana kualitas sumber daya manusia merupakan kuncinya. Guna menghadapi tantangan dan peluang masa depan, maka isi dari pendidikan kejuruan yang akan diajarkan kepada para siswanya harus menampilkan sosok utuh karakteristik sumber daya manusia yang ideal sesuai dengan kebutuhan dan tuntutan era global, yaitu karakteristik kualitas dasar yang kuat dan karakteristik kualitas instrumental yang dinamis (Nahriana, 2009).

Pendidikan berbasis ganda sesuai kebijakan link and match, mengharapkan agar kompetensi pendidikan kejuruan dilaksanakan di dua tempat. Sebagian kompetensi pendidikan dilaksanakan di sekolah, yaitu teori dan praktik dasar kejuruan, dan sebagian lainnya dilaksanakan di dunia kerja, yaitu keterampilan produktif yang diperoleh melalui prinsip learning by doing.

Memasuki era perdagangan bebas mulai tahun 2003 untuk Asia Tenggara dan 2010 untuk Asia Afrika, DUDI sebagai pengguna tenaga kerja harus melakukan peningkatan kompetensi tenaga kerjanya agar dapat bersaing di pasar bebas. Konsekuensi dari kondisi tersebut adalah SMK sebagai lembaga pendidikan formal yang memberikan bekal keterampilan dan pengetahuan dituntut untuk dapat mengikuti ritme yang berkembang di DUDI. Untuk mampu bersaing di pasar kerja, siswa SMK harus dibekali dengan kompe- 
tensi-kompetensi yang luwes yang mencakup kompetensi kunci dan kompetensi pada bidang keahlian tertentu (Soenaryo, dkk., 2002). Menjawab tantangan kualifikasi SDM diera globalisasi tersebut, prakerin yang dilaksanakan oleh SMK dapat menjadi batu loncatan bagi penyiapan tenaga yang terampil, kompeten, dan berdaya saing global. Penyelenggaraan prakerin sebaiknya merupakan pelatihan terintegrasi berbasis kompetensi.

Sekolah Menengah Kejuruan Negeri 1 Pengasih (SMKN 1 Pengasih) pada awalnya merupakan SMK Bidang Studi Keahlian Bisnis dan Manajemen favorit di wilayah Kabupaten Kulon Progo. Hal ini terbukti dari tingginya animo (jumlah pendaftar) pada setiap penerimaan calon siswa baru. Melihat animo masyarakat yang begitu besar, pada perkembangannya, SMK N 1 Pengasih memiliki tiga bidang studi keahlian yaitu (1) teknologi informasi dan komunikasi, (2) seni, kerajinan dan pariwisata, dan (3) bisnis dan manajemen. Dari tiga bidang studi keahlian tersebut terdapat enam kompetensi keahlian, salah satunya yaitu kompetensi keahlian pemasaran. Kompetensi keahlian pemasaran memiliki dua kelas paralel yaitu pemasaran 1 (PM1) dan pemasaran 2 (PM2) mulai kelas X sampai dengan kelas XII dengan masingmasing memiliki daya tampung 33 siswa (Ketua Kompetensi Keahlian Pemasaran, 4 Juni 2011).

Besarnya animo masyarakat menunjukkan input siswa SMKN 1 Pengasih tergolong baik. Input yang sudah baik tersebut harus diimbangi dengan proses dan output yang baik pula. Output siswa salah satunya dapat dilihat dari kompetensi lulusannya. Aspek yang turut mendukung standar kompetensi lulusan ialah prakerin. Lulusan akan memiliki kompetensi yang baik apabila prakerin dilaksanakan dengan baik, karena prakerin melibatkan berbagai aspek yang ada di sekolah, mulai dari perencanaan program hingga evaluasi pelaksanaan prakerin. Saat prakerin, siswa benarbenar dihadapkan pada kondisi riil suatu pekerjaan dan lingkungan kerja. Dengan demikian pelaksanaan prakerin dapat dijadikan sebagai tolok ukur kinerja SMK terhadap kualitas lulusannya.

Dilihat dari sudut pandang konteks, input, proses, dan produk dapat diketahui berbagai aspek yang mendukung pelaksanaan prakerin. Pada komponen konteks dapat di- lihat sejauhmana sekolah merencanakan prakerin baik dalam hal administratif, sarana dan prasarana maupun sumberdaya manusia. Pada komponen input dapat diketahui kesiapan siswa, guru, instruktur lapangan, sarana dan prasarana untuk melaksanakan prakerin. Pada komponen proses, siswa merupakan praktikan yang dimonitor oleh guru pembimbing dan instruktur. Pada komponen produk dapat di lihat kemanfaatan prakerin yang telah dilaksanakan. Empat komponen tersebut saling berkaitan sehingga pelaksanaan prakerin ditentukan oleh berbagai aspek dalam tiap komponen tersebut. Salah satu aspek di setiap komponen kurang baik maka akan mempengaruhi komponen yang lain, dan akhirnya akan mempengaruhi pelaksanaan prakerin secara keseluruhan.

Sekolah Menengah Kejuruan Negeri 1 Pengasih memiliki kebijakan bahwa segala sesuatu mengenai prakerin diurus oleh suatu bagian yang disebut kelompok kerja prakerin (pokja prakerin). Pokja prakerin bertugas menyiapkan keperluan administratif mulai dari perijinan sampai dengan evaluasi prakerin. Berdasarkan hasil evaluasi yang dilakukan oleh pokja prakerin pada tahun-tahun sebelumnya masih terdapat berbagai kekurangan dalam pelaksanaan prakerin. Hal ini diungkapkan oleh pokja prakerin pada saat observasi bahwa masih terdapat beberapa kekurangan pada pelaksanaan prakerin. Salah satu kekurangan tersebut pada prosedur dan aturan yang diperlukan, yaitu prosedur dan aturan berapa kali minimal kunjungan guru pembimbing ke DUDI pada saat prakerin serta lembar monitoring guru pembimbing.

Berdasarkan hasil pra survei (7 Mei 2011) di DUDI mitra SMK N 1 Pengasih, berbagai keterbatasan yang dimiliki baik oleh pihak sekolah maupun siswa dapat menimbulkan ketidaksesuaian antara apa yang diharapkan sekolah dengan apa yang ada di DUDI. Salah satu contoh keterbatasan tersebut adalah kompetensi yang diperoleh saat prakerin belum mencerminkan seluruh kompetensi yang harus dimiliki oleh siswa. Hal ini dikemukakan oleh beberapa DUDI bahwa tidak semua kompetensi yang diberikan oleh sekolah sebagai acuan pada saat prakerin dapat diberikan. Keterbatasan waktu pelaksanaan prakerin juga menjadi salah satu faktor yang menentukan kompetensi siswa tersebut. DUDI menyatakan bahwa waktu prakerin empat 
bulan belum mencukupi untuk melatihkan berbagai kompetensi profesional bagi siswa untuk bekerja.

Perbedaan yang mendasar antara sistem nilai yang berlaku di sekolah dengan yang berlaku di dunia kerja menuntut sekolah untuk benar-benar mempersiapkan siswanya sebelum masuk dunia kerja. Persiapan tersebut meliputi pengetahuan kerja, keterampilan kerja, sikap/budaya kerja, dan informasi tentang kebutuhan industri pasangannya tentang kemampuan dasar kerja yang harus dikuasai siswa sebelum diterjunkan dalam praktik di dunia kerja. Informasi awal yang diberikan oleh Ketua Kompetensi Keahlian Pemasaran SMK N 1 Pengasih, persiapan menjelang prakerin diberikan dalam bentuk pembekalan yang dilaksanakan mendekati penerjunan/penyerahan siswa ke DUDI. Implikasinya adalah siswa belum mendapatkan persiapan yang matang untuk bekal prakerin. Seperti yang dikatakan oleh siswa pada saat observasi bahwa mereka mengaku belum begitu memahami tentang DUDI dan belum siap secara total untuk prakerin karena keterbatan informasi mengenai hal itu.

Berbagai kajian dan sumber menyebutkan bahwa pelaksanaan pembelajaran komponen pendidikan adaptif dan teori kejuruan menjadi tanggung jawab sekolah. Komponen pendidikan praktik dasar profesi dilaksanakan sesuai dengan kesepakatan antara sekolah dengan DUDI pasangannya, sedangkan komponen pendidikan praktik keahlian profesi menjadi tanggung jawab industri pasangan masing-masing sekolah dalam pelaksanaan prakerin. Kebijakan ini muncul karena disadari bahwa penguasaan keahlian profesional yang sebenarnya hanya dapat dicapai melalui kerja nyata di tempat kerja yang sebenarnya dan bukan di sekolah. Sekolah hanya mampu memberikan kemampuan dasar kejuruan yang kuat, sehingga dengan bekal kemampuan dasar kejuruan yang kuat dapat membantu siswa dalam mendalami pelatihan-pelatihan kerja yang lebih kompleks dan spesifik di dunia kerja. Dengan demikian, kemitraan SMK dengan dunia usaha dan industri bukan lagi merupakan hal penting, tetapi merupakan keharusan.

Anas Arfandi (2009) dalam tesisnya yang berjudul evaluasi pelaksanaan praktik kerja industri siswa SMK Kompetensi Keahlian Teknik Bangunan di Kota Makassar me- nyebutkan masih adanya beberapa hal yang perlu diperbaiki yaitu kerja sama yang terbangun antara industri dan sekolah masih kurang baik terutama pada indudtri-industri golongan kecil, sementara industri golongan menengah dan besar masih cukup baik walaupun sangat terbatas. Dari sisi keterampilan dasar siswa masih kurang mampu bekerja secara praktis di DUDI.

Senada dengan evaluasi yang telah dilakukan tersebut, evaluasi prakerin yang telah dilakukan untuk siswa kompetensi keahlian penyuluhan pertanian di Kalsel oleh Yuli (2012) menyebutkan bahwa masih ada beberapa hal yang masih kurang. Pada aspek konteks khususnya pengetahuan siswa tentang dunia kerja masih kurang. Pada aspek input, masih terdapat kekurangan yaitu pada tingginya biaya prakerin, peralatan yang masih sederhana, ada sebagian materi yang belum tersampaikan di sekolah sebelum pelaksanaan prakerin, dan kinerja pembimbing internal belum maksimal. Fakta tersebut menunjukkan bahwa meskipun prakerin telah lama dilaksanakan dan menjadi program rutin namun pelaksanaannya belum optimal. Evaluasi oleh pihak internal sekolah selalu dilakukan pada akhir pelaksanaan prakerin seperti yang dilakukan oleh kompetensi keahlian pemasaran SMKN 1 Pengasih. Akan tetapi hasilnya belum dapat memberikan informasi menyeluruh pada semua aspek.

Beberapa evaluasi tentang prakerin telah dilakukan. Namun penelitian tentang evaluasi prakerin kompetensi keahlian pemasaran dengan pendekatan metode konteks, input, proses, produk masih minim. Metode tersebut dapat digunakan untuk mengevaluasi pelaksaan program. Minimnya informasi mengenai pelaksanaan prakerin khususnya Kompetensi Keahlian Pemasaran menjadi alasan utama dalam penelitian ini. Kesesuaian antara apa yang diharapkan pihak sekolah dengan apa yang ada di DUDI menjadi kajian utama dalam penelitian ini. Hal ini penting karena SMK akan mendapatkan masukan mengenai hal tersebut yang dapat digunakan untuk mengevaluasi salah satu kriteria kinerja SMK yaitu prakerin. Selain itu, perbedaan orientasi pelaksanaan prakerin yang belum jelas antara apa yang diharapkan oleh sekolah dengan apa yang diharapkan oleh DUDI menyebabkan keragaman penerapan prakerin di setiap DUDI. Berdasarkan uraian di atas, maka perlu 
dilakukan evaluasi terhadap prakerin Kompetensi Keahlian Pemasaran Sekolah Menengah Kejuruan Negeri 1 Pengasih (SMK N 1 Pengasih) Kulon Progo dengan pendekatan metode konteks, input, proses, produk.

Penelitian ini bertujuan untuk mengevaluasi program praktik kerja industry kompetensi keahlian pemasaran SMKN 1 Pengasih, Kulon Progo dilihat dari konteks, input, proses, dan produk. Manfaat praktis penelitian ini yaitu Penelitian ini dapat digunakan sebagai bahan evaluasi bagi sekolah khususnya SMK N 1 Pengasih dan sekolahsekolah lain dalam hal pelaksanaan prakerin agar pelaksanaan prakerin dapat menuju ideal baik dari aspek siswa, sekolah, maupun DUDI. Secara teotetis, penelitian ini dapat memperkaya khazanah penelitian Pendidikan Teknologi dan Kejuruan yang bersumber dari pelaksanaan prakerin SMK. Berdasarkan pengamatan peneliti, masih belum banyak dijumpai penelitian yang mengupas tentang pelaksanaan prakerin Kompetensi Keahlian Pemasaran di sekolah.

\section{METODE PENELITIAN}

\section{Jenis Penelitian}

Jenis penelitian yang digunakan adalah evaluasi dengan pendekatan model CIPP (Context, Input, Process, Product).

\section{Waktu dan Tempat Penelitian}

Penelitian ini dilakukan di SMK N 1 Pengasih pada Kompetensi Keahlian Pemasaran dan di DUDI mitra sebanyak 5 DUDI. Penelitian dilaksanakan pada bulan September 2011 sampai dengan bulan Januari 2012.

\section{Populasi dan Sampel}

Populasi penelitian ini adalah siswa yang telah melaksanakan prakerin yaitu siswa kelas XI dan XII tahun pelajaran 2010/2011 dan 2011/2012 sebanyak 126 siswa. Guru pembimbing sebanyak 7 orang guru, dan instruktur sebanyak 9 orang. Untuk kepentingan cross check data dilakukan melalui wawancara dengan ketua kompetensi keahlian pemasaran dan kelompok kerja (pokja) prakerin sebanyak 3 orang.

Sampel yang digunakan dalam penelitian ini diambil dengan menggunakan meto- de simple random sampling. Sampel siswa diambil 75 siswa yang terdiri dari 40 siswa kelas XI dan 35 siswa kelas XII, 7 orang guru pembimbing, dan 5 orang instruktur.

\section{Data, Intrumen, dan Teknik Pengumpulan Data}

Teknik pengumpulan data yang digunakan dalam penelitian ini adalah angket, observasi, wawancara, dan dokumentasi. Instrumen/alat yang digunakan adalah lembar angket, pedoman observasi, pedoman wawancara, dan pedoman dokumentasi.

\section{Teknik Analisis Data}

Data yang sudah diperoleh kemudian dianalisis dengan langkah-langkah 1) menskor jawaban responden, 2) menjumlahlan skor total masing-masing aspek, 3) mengelompokkan skor yang diperoleh responden berdasarkan tingkat kecenderungan, dan 4) melihat persentase tingkat kecenderungan dengan kategori yang ada untuk mendapatkan informasi mengenai hasil penelitian tersebut. Skala penskoran yang digunakan dalam penelitian ini ialah skala empat: 1, 2, 3, dan 4.

Kriteria penilaian untuk masing-masing aspek disajikan pada Tabel 1 .

Tabel 1. Pedoman Kriteria Penilaian

\begin{tabular}{l|l}
\hline \multicolumn{1}{c|}{ Interval Nilai } & \multicolumn{1}{c}{ Kategori } \\
\hline $\mathrm{X}<\mathrm{Mi}-1 \mathrm{SDi}$ & $\begin{array}{l}\text { Tidak Relevan/ } \\
\text { Tidak Baik }\end{array}$ \\
\hline $\mathrm{Mi}-1 \mathrm{SDi} \leq \mathrm{X}<\mathrm{Mi}$ & $\begin{array}{l}\text { Kurang Relevan/ } \\
\text { Kurang Baik }\end{array}$ \\
\hline $\mathrm{Mi} \leq \mathrm{X}<\mathrm{Mi}+\mathrm{SDi}$ & $\begin{array}{l}\text { Relevan/ } \\
\text { Baik }\end{array}$ \\
\hline $\mathrm{X} \geq \mathrm{Mi}+1 \mathrm{SDi}$ & $\begin{array}{l}\text { Sangat Relevan/ } \\
\text { Sangat Baik }\end{array}$ \\
\hline
\end{tabular}

Sumber: Saifuddin Azwar (2012: 149)

Keterangan:

Mi $:$ Mean ideal $=1 / 2$ (skor tertinggi + skor terendah)

SDi : Simpangan baku ideal $=1 / 6$ (skor tertinggi - skor terendah)

Pedoman kriteria penilaian pada Tabel 1 tersebut digunakan untuk perhitungan dengan menggunakan mean total. Sedangkan 
untuk perhitungan mean per item pertanyaan digunakan kriteria penilaian pada Tabel 2 . Gambaran perhitungan dengan menggunakan mean per item pertanyaan disampaikan berikut ini.

Skor tertinggi $=4$

Skor terendah $=1$

Mi

$$
: 1 / 2(4+1)=2,5
$$

Sdi $: 1 / 6(4-1)=0,5$

Skala $4: X \geq 2,5+(1 \times 0,5)=X \geq 3,0$

Skala $3: 2,5 \leq \mathrm{X}<2,5+(1 \times 0,5)=2,5 \leq \mathrm{X}<3,0$

Skala $2: 2,5-(1 \times 0,5) \leq X<2,5=2,0 \leq X<2,5$

Skala 1 : $X<2,0$

Berdasarkan hasil perhitungan tersebut, dibuat standar skor kategori kecenderungan variabel dan komponen yang dipakai sebagai kriteria dalam melakukan evaluasi. Analisis statistik deskriptif menggunakan pernyataan sangat relevan/sangat baik, relevan/baik, kurang relevan/kurang baik, tidak relevan/tidak baik seperti dalam tabel berikut ini.

Tabel 2. Kriteria penilaian

\begin{tabular}{cc}
\hline Interval nilai & Kategori \\
\hline $\mathrm{X} \geq 3,0$ & Sangat relevan/sangat baik \\
$2,5 \leq \mathrm{X}<3,0$ & Relevan/baik \\
$2,0 \leq \mathrm{X}<2,5$ & Kurang relevan/kurang \\
$\mathrm{X}<2,0$ & baik \\
& Tidak relevan/tidak baik \\
\hline
\end{tabular}

\section{HASIL PENELITIAN DAN PEMBAHASAN}

Siswa kompetensi keahlian pemasaran melaksanakan prakerin dalam durasi waktu empat bulan. Waktu tersebut sudah sesuai dengan aturan dari Departemen Pendidikan dan Kebudayaan (Depdikbud) yang menyaratkan pelaksanaan prakerin berdurasi antara empat sampai dengan tujuh bulan. Pemilihan durasi empat bulan karena siswa juga harus menyelesaikan teori mereka yang sudah ditargetkan sesuai kurikulum sekolah.

Berdasarkan kebijakan yang dibuat oleh sekolah, prakerin dilaksanakan dalam dua tahap. Kebijakan yang diambil ini menurut keterangan ketua kompetensi keahlian pemasaran sesuai masukan dari DUDI. Sewaktu prakerin dilaksanakan selama empat bulan berturut-turut, DUDI melihat adanya kejenuh- an siswa pada bulan ketiga pelaksanaan prakerin. Atas dasar hal tersebut maka empat tahun terakhir pelaksanaan prakerin dibagi dalam dua tahap, masing-masing dua bulan, pada semester keempat.

Pelaksanaan prakerin tahap pertama di DUDI selama dua bulan, tahap kedua ada yang dilaksanakan di DUDI dan ada yang di sekolah. Sebagian siswa melanjutkan prakerin di DUDI sebagian lainnya melaksanakan prakerin di sekolah mengikuti program praktik kewirausahaan yang dilakukan di bisnis centre. Hal ini dilakukan karena sekolah memiliki program praktik kewirausahaan yang bertujuan untuk membekali siswa dengan keterampilan berwira usaha. Sehingga siswa dapat mengembangkan keterampilan berwira usaha di bisnis centre tersebut. Adapun kegiatan selama praktik di DUDI dan bisnis centre menurut keterangan ketua kompetensi keahlian pemasaran hampir sama. Perbedaan yang paling menonjol adalah dalam hal lingkungan kerja. Meski demikian siswa tetap dapat melakukan kegiatan sesuai kompetensi materi pembelajaran prakerin.

Prakerin di SMK N 1 Pengasih secara keseluruhan ditangani oleh kelompok kerja (pokja) prakerin. Pokja menyiapkan berbagai hal yang bersifat administratif, mulai dari berkas perijinan sampai dengan berkas penarikan dan evaluasi. Pokja berkoordinasi dengan semua ketua kompetensi keahlian yang ada di SMKN 1 Pengasih. Dengan kata lain pokja prakerin mengurusi prakerin seluruh kompetensi keahlian yang ada di SMKN 1 Pengasih.

\section{Evaluasi Konteks}

Evaluasi konteks dilakukan untuk mengetahui perencanaan dan kesesuaian program prakerin menurut guru pembimbing, siswa, dan instruktur. Hasil wawancara dan observasi mengenai aspek konteks menunjukkan bahwa prakerin direncanakan sesuai dengan kebutuhan sekolah, siswa, maupun DUDI. Menurut keterangan guru, program yang disusun disesuaikan dengan kurikulum sekolah, akan tetapi program tersebut belum melibatkan DUDI dalam merumuskannya. Perencanaan secara administratif dilakukan oleh pokja prakerin dengan sangat baik. Terbukti dengan kelengkapan dokumen yang diperlukan untuk prakerin sudah tersedia dengan baik. 
Sarana dan prasarana untuk menunjang pelaksanaan prakerin tergolong baik diantaranya ialah adanya laboratorium praktik untuk melatih kompetensi dasar siswa, meskipun untuk jumlah peralatan belum memadai. Sumberdaya manusia pendukung program prakerin telah dirancang dan dialokasikan sesuai dengan kebutuhan. Secara umum, aspek konteks dari hasil wawancara dan observasi termasuk dalam kategori sangat relevan/ sangat baik.

Berdasarkan data angket, angket yang diberikan kepada guru terdiri dari tujuh butir pertanyaan dengan empat pilihan jawaban. Hasil pengolahan data menunjukkan mean sebesar 24,29; median sebesar 24,00; modus sebesar 23; standar deviasi sebesar 1,98; minimum sebesar 22; maksimum sebesar 27. Distribusi frekuensi dan persentase pendapat guru pada aspek konteks dapat dilihat pada tabel 3 .

Tabel 3. Kategori Pendapat Guru terhadap Aspek Konteks

\begin{tabular}{cccc}
\hline Interval Nilai & Kategori & Frek. & $\begin{array}{c}\text { Frek. } \\
\text { Relatif (\%) }\end{array}$ \\
\hline $\mathrm{X}<14$ & $\begin{array}{c}\text { Tidak } \\
\text { Relevan/ } \\
\text { Tidak Baik } \\
\text { Kurang } \\
\text { Relevan/ } \\
\text { Kung Baik } \\
\text { Revan/ } \\
\text { Baik }\end{array}$ & 0 & 0 \\
$\mathrm{X} \geq 217 \mathrm{X}<21 \quad \begin{array}{c}\text { Sangat } \\
\text { Relevan/ } \\
\text { Sangat Baik }\end{array}$ & 7 & 100 \\
Jumlah & 7 & 100 \\
\hline
\end{tabular}

Untuk memperjelas data pada tabel 3 dapat dilihat pada diagram lingkaran di bawah ini.

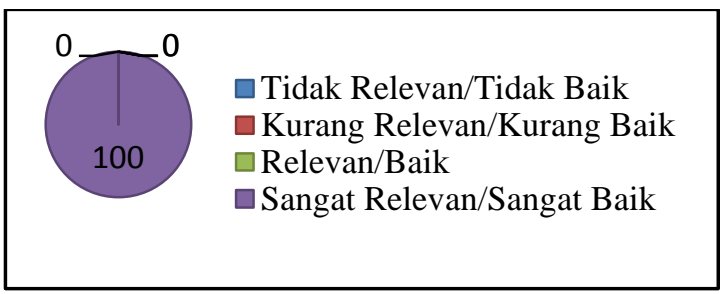

Gambar 1. Diagram Lingkaran Pendapat Guru terhadap Aspek Konteks
Secara umum dapat disimpulkan bahwa pendapat guru pembimbing terhadap aspek konteks termasuk dalam kategori sangat relevan/sangat baik. Hal ini menunjukkan bahwa menurut guru, program prakerin telah direncanakan dengan sangat baik dan sangat relevan dengan kebutuhan siswa maupun DUDI.

Dari hasil pengolahan data siswa dapat diketahui hasil sebagai berikut: rerata sebesar 18,56; median sebesar 18,00; modus sebesar 18; standar deviasi sebesar 1,88; minimum sebesar 12; maksimum sebesar 22. Distribusi frekuensi kategori pendapat seluruh siswa terhadap aspek konteks disajikan pada Tabel 4.

Tabel 4. Kategori pendapat siswa terhadap aspek konteks

\begin{tabular}{|c|c|c|c|}
\hline Interval Nilai & Kategori & Frek. & $\begin{array}{c}\text { Frek. } \\
\text { Relatif }(\%)\end{array}$ \\
\hline$X<12$ & $\begin{array}{c}\text { Tidak } \\
\text { Relevan/ } \\
\text { Tidak Baik }\end{array}$ & 0 & 0 \\
\hline $12 \geq X<15$ & $\begin{array}{c}\text { Kurang } \\
\text { Relevan/ } \\
\text { Kurang Baik }\end{array}$ & 1 & 1,3 \\
\hline $15 \geq X<18$ & $\begin{array}{l}\text { Relevan/ } \\
\text { Baik }\end{array}$ & 21 & 28,0 \\
\hline$X \geq 18$ & $\begin{array}{c}\text { Sangat } \\
\text { Relevan/ } \\
\text { Sangat Baik }\end{array}$ & 53 & 70,7 \\
\hline \multicolumn{2}{|c|}{ Jumlah } & 75 & 100 \\
\hline
\end{tabular}

Untuk memperjelas data pada tabel 4 dapat dilihat pada diagram lingkaran berikut ini.

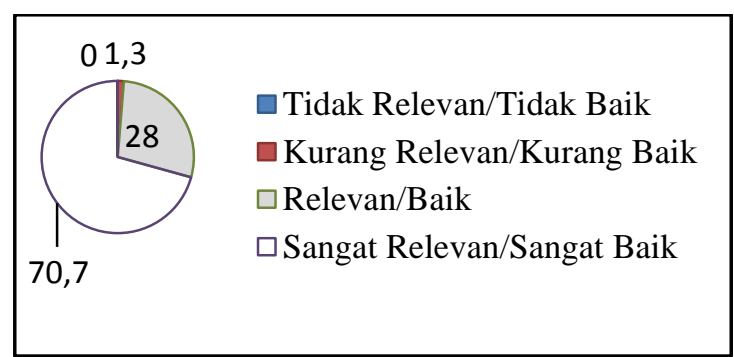

Gambar 2. Diagram Lingkaran Pendapat Siswa terhadap Aspek Konteks

Secara umum dapat disimpulkan bahwa pendapat siswa pada aspek konteks termasuk dalam kategori sangat relevan/sangat baik. Hal ini berarti menurut siswa, perencanaan 
program prakerin telah dilakukan dengan sangat baik oleh sekolah dengan mempertimbangkan relevansinya bagi kebutuhan siswa dengan sangat baik.

Hasil wawancara dan observasi yang dilakukan diketahui bahwa dalam hal perencanaan prakerin pihak DUDI tidak merencanakan secara khusus, hanya mengikuti panduan dari sekolah. Salah seorang instruktur menyebutkan bahwa program selama prakerin tidak dapat sepenuhnya mengikuti panduan dari sekolah, tetapi menyesuaikan dengan kondisi DUDI.

Berdasarkan data angket, angket untuk instruktur terdiri dari enam butir pertanyaan. Hasil pengolahan data diperoleh nilai Rerata sebesar 18,00; median sebesar 18,00; modus sebesar 12; standar deviasi sebesar 3,94; nilai minimum sebesar 12 dan nilai maksimum sebesar 22. Distribusi frekuensi pendapat instruktur terhadap aspek konteks disajikan pada Tabel 5.

Tabel 5. Kategori Pendapat Instruktur terhadap Aspek Konteks

\begin{tabular}{|c|c|c|c|}
\hline $\begin{array}{c}\text { Interval } \\
\text { Nilai }\end{array}$ & Kategori & Frek. & $\begin{array}{c}\text { Frek. } \\
\text { Relatif }(\%)\end{array}$ \\
\hline$X<12$ & $\begin{array}{c}\text { Tidak } \\
\text { Relevan/ } \\
\text { Tidak Baik }\end{array}$ & 0 & 0 \\
\hline $12 \leq X<15$ & $\begin{array}{c}\text { Kurang } \\
\text { Relevan/ } \\
\text { Kurang Baik }\end{array}$ & 1 & 20 \\
\hline $15 \leq X<18$ & $\begin{array}{c}\text { Relevan/ } \\
\text { Baik }\end{array}$ & 1 & 20 \\
\hline$X \geq 18$ & $\begin{array}{c}\text { Sangat } \\
\text { Relevan/ } \\
\text { Sangat Baik }\end{array}$ & 3 & 60 \\
\hline \multicolumn{2}{|c|}{ Jumlah } & 5 & 100 \\
\hline
\end{tabular}

Penyajian data pada tabel 5 dalam bentuk diagram lingkaran dapat dilihat pada gambar 3.

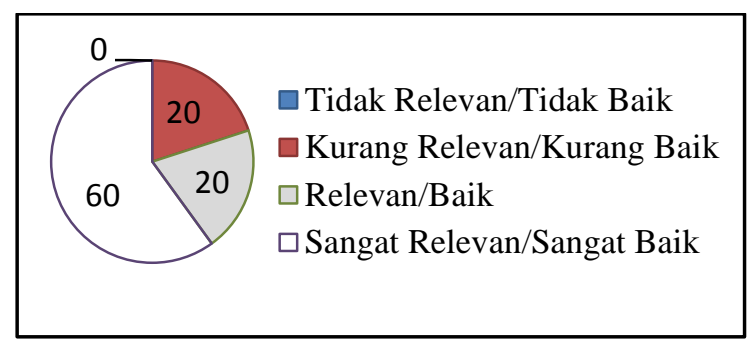

Gambar 3. Diagram Lingkaran Pendapat Instruktur terhadap Aspek Konteks
Mengacu pada pemaparan hasil data angket di atas, dapat disimpulkan bahwa pendapat instruktur prakerin terhadap aspek konteks termasuk dalam kategori sangat relevan/sangat baik. Menurut instruktur, perencanaan program prakerin sudah sangat baik dan sangat relevan dengan kebutuhan siswa.

\section{Evaluasi Input}

Evaluasi Input dilakukan untuk mengetahui persiapan pelaksanaan prakerin menurut guru pembimbing, siswa, dan instruktur. Hasil wawancara dan observasi diperoleh keterangan bahwa kesiapan prakerin dalam hal buku pedoman prakerin tidak baik. Diketahui pula bahwa sekolah tidak memiliki buku panduan prakerin secara utuh. Penjelasan tentang prakerin hanya berupa lembaran-lembaran dokumen yang terpisah-pisah. Dalam hal pembekalan kepada siswa, ditemukan data bahwa pembekalan dilakukan seminggu sebelum pelaksanaan. Materi yang diberikan berupa manajemen diri, motivasi, serta pemberian seperangkat dokumen yang dibutuhkan selama pelaksanaan prakerin berupa buku catatan harian kegiatan.

Mengacu pada teori tahapan persiapan prakerin yang disebutkan pada Bab II, idealnya pembekalan yang diberikan kepada siswa meliputi pembekalan pengetahuan, keterampilan, serta cara belajar di DUDI (Tamrin, 2008). Data yang diperoleh mengindikasikan bahwa pembekalan kepada siswa tidak sesuai dengan yang seharusnya. Pembekalan yang dilakukan terkesan alakadarnya, sederhana, tidak memperhatikan aspek-aspek yang seharusnya diberikan kepada siswa. Hal ini berdampak pada kurangnya pengetahuan dan pemahaman siswa mengenai DUDI.

Hasil pengolahan angket untuk siswa kompetensi keahlian pemasaran SMKN 1 Pengasih pada aspek Input menunjukkan bahwa Rerata sebesar 21,24; median sebesar 21,00; mode sebesar 24; standar deviasi sebesar 3,27; nilai minimum sebesar 11 dan nilai maksimum sebesar 31. Distribusi frekuensi pendapat siswa pada aspek Input disajikan pada Tabel 6. 
Tabel 6. Kategori Pendapat Siswa pada Aspek Input

\begin{tabular}{cccc}
\hline $\begin{array}{c}\text { Interval } \\
\text { Nilai }\end{array}$ & Kategori & Frek. & $\begin{array}{c}\text { Frek. } \\
\text { Relatif }(\%)\end{array}$ \\
\hline $\mathrm{X}<18$ & $\begin{array}{c}\text { Tidak } \\
\text { Relevan/ } \\
\text { Tidak Baik } \\
\text { Kurang } \\
\text { Relevan/ } \\
\text { Kurang Baik } \\
\text { Relevan/ } \\
\text { Baik } \\
23 \leq \mathrm{X}<23\end{array}$ & 72 & 9,3 \\
27 & 24 & 36,0 \\
$\mathrm{X} \geq 27$ & $\begin{array}{c}\text { Sangat } \\
\text { Relevan/ } \\
\text { Sangat Baik }\end{array}$ & 2 & 2,7 \\
Jumlah & 75 & 100 \\
\hline
\end{tabular}

Penyajian data pada tabel 38 dalam bentuk diagram lingkaran pada Gambar 4 .

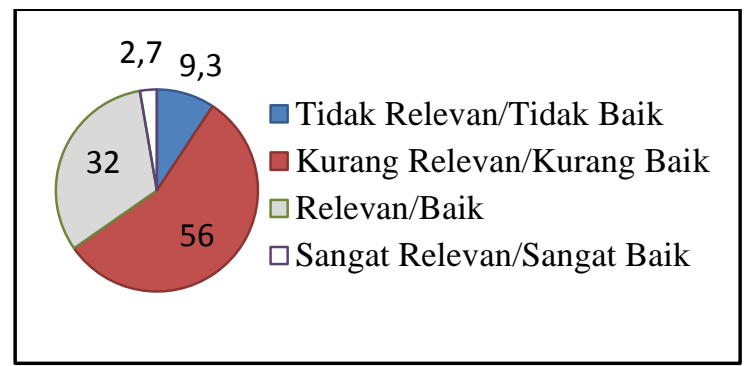

Gambar 4. Diagram Lingkaran Pendapat Siswa pada Aspek Input

Secara garis besar, dapat disimpulkan bahwa pendapat siswa pada aspek Input atau persiapan prakerin termasuk dalam kategori kurang relevan/kurang baik. Ini mengindikasikan bahwa sebagian besar siswa merasa kurang baik dalam mempersiapkan prakerin. Sekolah harus mencari alternatif solusi memberikan pemahaman kepada siswa mengenai prakerin semenjak di kelas $\mathrm{X}$ dalam setiap mata pelajaran produktif.

Aspek input menurut instruktur, berdasarkan pengolahan data diperoleh nilai rerata sebesar 15,00; median sebesar 15,00; modus sebesar 10; standar deviasi sebesar 3,39; nilai minimum sebesar 10 dan nilai maksimum sebesar 19. Distribusi frekuensi pendapat instruktur terhadap aspek Input disajikan pada Tabel 7.
Tabel 7. Kategori Pendapat Instruktur terhadap Aspek Input

\begin{tabular}{cccc}
\hline $\begin{array}{c}\text { Interval } \\
\text { Nilai }\end{array}$ & Kategori & Frek. & $\begin{array}{c}\text { Frek. } \\
\text { Relatif }(\%)\end{array}$ \\
\hline $\mathrm{X}<10$ & $\begin{array}{c}\text { Tidak } \\
\text { Relevan/ } \\
\text { Tidak Baik } \\
\text { Kurang } \\
\text { Relevan/ } \\
\text { Kung Baik } \\
\text { Relevan/ } \\
\text { Baik } \\
13 \leq \mathrm{X}<13\end{array}$ & 1 & 0 \\
$\mathrm{X} \geq 15$ & $\begin{array}{c}\text { Sangat } \\
\text { Relevan/ } \\
\text { Sangat Baik } \\
\text { Jumlah }\end{array}$ & 3 & 60 \\
\hline
\end{tabular}

Penyajian data pada tabel 7 dalam bentuk diagram lingkaran dapat Gambar 5.

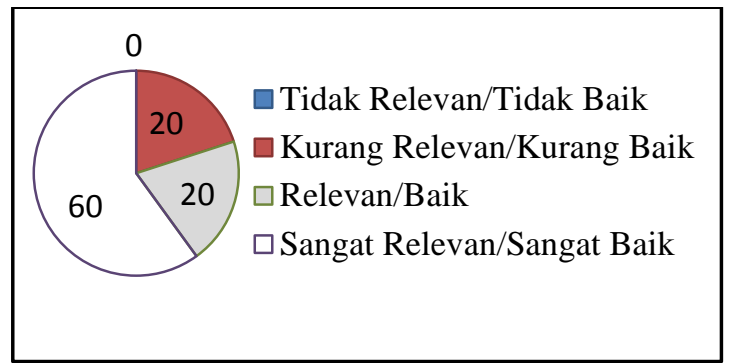

Gambar 5. Diagram Lingkaran Pendapat Instruktur terhadap Aspek Input

Data tersebut sedikit berbeda dengan data yang diperoleh melalui wawancara. Wawancara yang dilakukan kepada instruktur untuk mengetahui aspek Input meliputi pemahaman instruktur terhadap buku panduan, penjelasan jenis pekerjaan kepada siswa, pengarahan kepada siswa sebelum melaksanakan jenis pekerjaan tertentu, penjelasan mekanisme kerja di DUDI, monitoring terhadap kegiatan siswa. Berdasarkan data hasil wawancara diketahui bahwa instruktur tidak memperoleh buku panduan prakerin dari sekolah, hanya materi kegiatan siswa selama prakerin sehingga pemahaman instruktur sebatas pada materi kegiatan siswa. Instruktur memberikan pengarahan, penjelasan terhadap jenis pekerjaan dan mekanisme kerja di DUDI pada saat pertama siswa datang atau pada hari pertama pelaksanaan prakerin. Monitoring instruktur terhadap kegiatan siswa dilakukan baik secara langsung dengan melihat kinerja 
siswa, bertanya kepada pegawai yang bersinggungan langsung dengan siswa ataupun melalui catatan harian siswa. Secara umum, hasil wawancara mengenai pendapat instruktur terhadap aspek Input termasuk dalam kategori relevan/baik. Hasil wawancara dan observasi ini yang dianggap lebih mewakili kondisi nyata dari pada data hasil pengolahan angket yang disebutkan pada pemaparan sebelumnya.

Mengacu pada pemaparan tersebut, dapat disimpulkan bahwa pendapat instruktur prakerin terhadap aspek Input termasuk dalam kategori relevan/baik. Menurut instruktur, persiapan prakerin sudah dilakukan dengan baik.

\section{Evaluasi Proses}

Evaluasi proses dilakukan untuk mengetahui proses pelaksanaan prakerin di lapangan menurut guru pembimbing, siswa, dan instruktur. Menurut guru pembimbing, mengacu pada pengolahan data diperoleh rerata sebesar 18,14; median sebesar 19,00; modus sebesar 20; standar deviasi sebesar 2,34; minimum sebesar 14; maksimum sebesar 20. Distribusi frekuensi pendapat guru terhadap aspek proses disajikan pada Tabel 8.

Tabel 8. Kategori Pendapat Guru terhadap Aspek Proses

\begin{tabular}{cccc}
\hline $\begin{array}{c}\text { Interval } \\
\text { Nilai }\end{array}$ & Kategori & Frek. & $\begin{array}{c}\text { Frek. } \\
\text { Relatif }(\%)\end{array}$ \\
\hline $\mathrm{X}<12$ & $\begin{array}{c}\text { Tidak } \\
\text { Relevan/ } \\
\text { Tidak Baik } \\
\text { Kurang } \\
\text { Relevan/ } \\
\text { Kurang Baik } \\
\text { Relevan/ } \\
\text { Baik } \\
15 \leq \mathrm{X}<18\end{array}$ & 1 & 0 \\
$\mathrm{X} \geq 18$ & $\begin{array}{c}\text { Sangat } \\
\text { Relevan/ } \\
\text { Sangat Baik } \\
\text { Jumlah }\end{array}$ & 5 & 14,3 \\
& 7 & 100 \\
\hline
\end{tabular}

Penyajian data pada Tabel 8 dalam bentuk diagram lingkaran dapat dilihat pada Gambar 6.

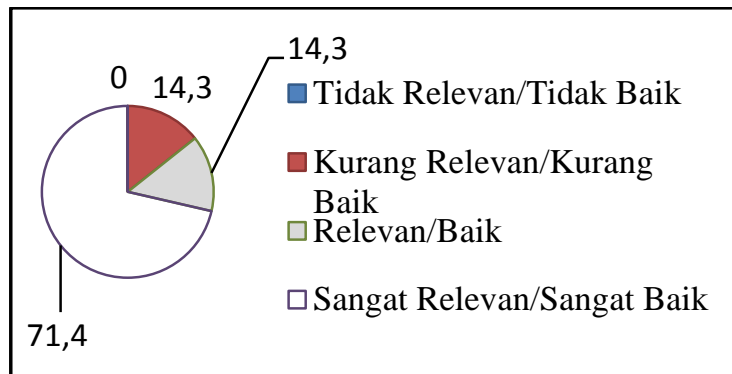

Gambar 6. Diagram Lingkaran Pendapat Guru terhadap Aspek Proses

Secara umum dapat disimpulkan bahwa pendapat guru pembimbing terhadap aspek proses termasuk dalam kategori sangat relevan/sangat baik. Hal ini menunjukkan bahwa menurut guru, pelaksanaan prakerin telah berjalan dengan baik dan relevan dengan kebutuhan siswa.

Menurut siswa, berdasarkan pengolahan data diperoleh Hasil pengolahan data mengenai pendapat siswa terhadap aspek proses diperoleh nilai rerata sebesar 52,53; median sebesar 52,00; modus sebesar 49; standar deviasi sebesar 4,10; nilai minimum sebesar 45 dan nilai maksimum sebesar 62. Distribusi frekuensi pendapat siswa terhadap aspek proses dapat dilihat pada tabel 9 .

Tabel 9. Kategori Pendapat Siswa terhadap Aspek Proses

\begin{tabular}{|c|c|c|c|}
\hline $\begin{array}{c}\text { Interval } \\
\text { Nilai }\end{array}$ & Kategori & Frek. & $\begin{array}{c}\text { Frek. } \\
\text { Relatif }(\%)\end{array}$ \\
\hline$X<36$ & $\begin{array}{c}\text { Tidak } \\
\text { Relevan/T } \\
\text { idak Baik }\end{array}$ & 0 & 0 \\
\hline $\begin{array}{c}36 \leq X \\
<45\end{array}$ & $\begin{array}{c}\text { Kurang } \\
\text { Relevan/ } \\
\text { Kurang Baik }\end{array}$ & 0 & 0 \\
\hline $\begin{array}{c}45 \leq \mathrm{X} \\
<54\end{array}$ & $\begin{array}{c}\text { Relevan/ } \\
\text { Baik }\end{array}$ & 50 & 66,7 \\
\hline$X \geq 54$ & $\begin{array}{c}\text { Sangat } \\
\text { Relevan/ } \\
\text { Sangat Baik }\end{array}$ & 25 & 33,3 \\
\hline \multicolumn{2}{|c|}{ Jumlah } & 75 & 100 \\
\hline
\end{tabular}

Penyajian data pada tabel 9 dalam bentuk diagram lingkaran pada Gambar 7. 


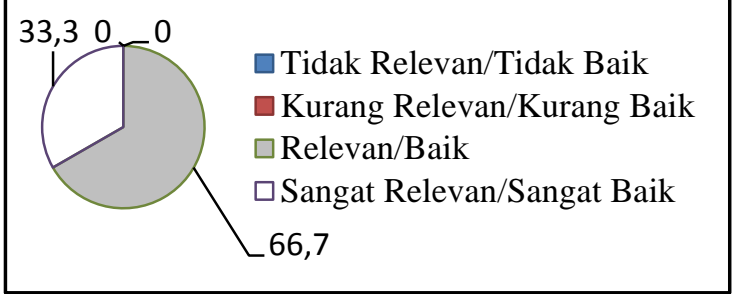

Gambar 7. Diagram Lingkaran Pendapat Siswa terhadap Aspek Proses

Menurut keterangan siswa, ketua kompetensi keahlian, dan pokja prakerin untuk kehadiran guru ditempat prakerin ada beberapa guru yang kurang memperhatikan. Hal itu disadari karena kesibukan masing-masing guru. Namun demikian sekolah perlu mengambil langkah agar para guru pembimbing yang telah berkomitmen untuk membimbing prakerin melaksanakan tugas monitoring dengan baik. dapat disimpulkan bahwa pendapat siswa terhadap aspek proses prakerin secara umum termasuk dalam kategori relevan/baik. Dengan kata lain, menurut siswa, pelaksanaan prakerin yang dilakukan di tiap DUDI sudah berjalan dengan baik.

Hasil pengolahan data instruktur, diperoleh nilai rerata sebesar 45,40; median sebesar 47,00; modus sebesar 35; standar deviasi sebesar 7,44; nilai minimum sebesar 35 dan nilai maksimum sebesar 55. Distribusi frekuensi dan persentase data disajikan berikut ini.

Tabel 10. Kategori Pendapat Instruktur terhadap Aspek Proses

\begin{tabular}{|c|c|c|c|}
\hline Interval Nilai & Kategori & Frek. & $\begin{array}{c}\text { Frek. } \\
\text { Relatif }(\%)\end{array}$ \\
\hline$X<30$ & $\begin{array}{c}\text { Tidak } \\
\text { Relevan/ } \\
\text { Tidak Baik }\end{array}$ & 0 & 0 \\
\hline $30 \leq X<37,5$ & $\begin{array}{c}\text { Kurang } \\
\text { Relevan/ } \\
\text { Kurang Baik }\end{array}$ & 1 & 20 \\
\hline $37,5 \leq X<45$ & $\begin{array}{c}\text { Relevan/ } \\
\text { Baik }\end{array}$ & 1 & 20 \\
\hline$X \geq 45$ & $\begin{array}{c}\text { Sangat } \\
\text { Relevan/ } \\
\text { Sangat Baik }\end{array}$ & 3 & 60 \\
\hline \multicolumn{2}{|c|}{ Jumlah } & 5 & 100 \\
\hline
\end{tabular}

Penyajian data pada tabel 10 dalam bentuk diagram pada Gambar 8 .

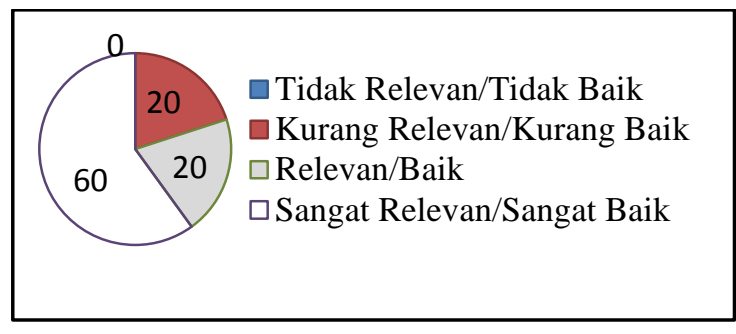

Gambar 8. Diagram Lingkaran Pendapat Instruktur terhadap Aspek Proses Pelaksanaan Prakerin

Secara umum dengan mengacu pada pemaparan di atas, dapat disimpulkan bahwa pendapat instruktur prakerin terhadap aspek proses termasuk dalam kategori sangat relevan/sangat baik. Menurut instruktur, proses pelaksanaan prakerin sudah dilakukan dengan sangat baik dan sangat relevan dengan kebutuhan siswa. Meskipun demikian diperoleh temuan bahwa menurut instruktur, hasil pembelajaran di DUDI selama prakerin tidak relevan untuk meningkatkan keterampilan siswa. Jawaban instruktur menunjukkan bahwa proses pelaksanaan prakerin khususnya dalam peningkatan keterampilan siswa kurang memberikan hasil yang baik. Hal ini karena tidak semua keterampilan dilatihkan selama prakerin.

\section{Evaluasi Produk}

Tabel 11. Kategori Pendapat Guru terhadap Aspek Produk

\begin{tabular}{|c|c|c|c|}
\hline Interval Nilai & Kategori & Frek. & $\begin{array}{l}\text { Frek. Relatif } \\
\qquad(\%)\end{array}$ \\
\hline$x<22$ & $\begin{array}{c}\text { Tidak } \\
\text { Relevan/ } \\
\text { Tidak Baik }\end{array}$ & 0 & 0 \\
\hline $22 \leq X<27,5$ & $\begin{array}{c}\text { Kurang } \\
\text { Relevan/ } \\
\text { Kurang Baik }\end{array}$ & 0 & 0 \\
\hline $27,5 \leq X<33$ & $\begin{array}{c}\text { Relevan } \\
\text { /Baik }\end{array}$ & 0 & 0 \\
\hline \multirow[t]{2}{*}{$X \geq 33$} & $\begin{array}{c}\text { Sangat } \\
\text { Relevan/ } \\
\text { Sangat Baik }\end{array}$ & 7 & 100 \\
\hline & lah & 7 & 100 \\
\hline
\end{tabular}

Evaluasi produk dilakukan untuk mengetahui kemanfaatan prakerin menurut guru pembimbing, siswa, dan instruktur. Hasil pengolahan data angket mengenai pendapat guru 
terhadap pelaksanaan prakerin pada aspek produk diperoleh rerata sebesar 39,43; median sebesar 39,00; modus sebesar 39; standar deviasi sebesar 3,36; minimum sebesar 33; maksimum sebesar 43 .

Penyajian data pada tabel 11 dalam bentuk diagram lingkaran dapat dilihat pada Gambar 9.

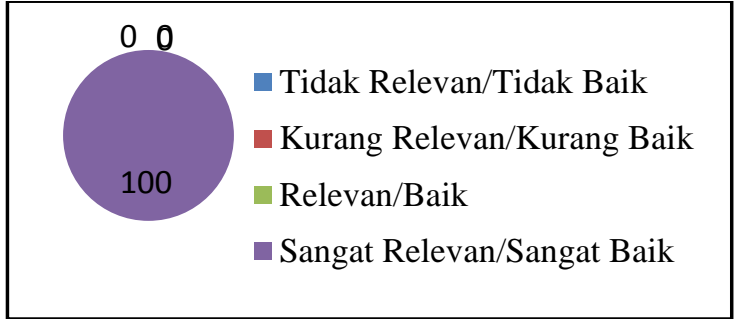

Gambar 9. Diagram Lingkaran Pendapat Guru terhadap Aspek Produk

Secara umum dapat disimpulkan bahwa pendapat guru pembimbing terhadap aspek produk termasuk dalam kategori sangat relevan/sangat baik. Hal ini menunjukkan bahwa menurut guru, program prakerin sangat bermanfaat bagi siswa dan sangat relevan dengan kebutuhan siswa.

Senada dengan pendapat guru, pendapat siswa terhadap aspek produk sebagai berikut. Hasil pengolahan data mengenai pendapat siswa terhadap aspek produk diperoleh nilai rerata sebesar 33,80; median sebesar 34,00; modus sebesar 33; standar deviasi sebesar 3,18; nilai minimum sebesar 21 dan nilai maksimum sebesar 41. Distribusi frekuensi data dapat dilihat pada tabel 12 .

Tabel 12. Kategori Pendapat Siswa terhadap Aspek Produk

\begin{tabular}{|c|c|c|c|}
\hline Interval Nilai & Kategori & Frek. & $\begin{array}{c}\text { Frek. } \\
\text { Relatif }(\%)\end{array}$ \\
\hline$X<22$ & $\begin{array}{c}\text { Tidak } \\
\text { Relevan/ } \\
\text { Tidak Baik }\end{array}$ & 1 & 1,3 \\
\hline $22 \leq X<27,5$ & $\begin{array}{c}\text { Kurang } \\
\text { Relevan/ } \\
\text { Kurang Baik }\end{array}$ & 0 & 0 \\
\hline $27,5 \leq X<33$ & Relevan/Baik & 21 & 28,0 \\
\hline$X \geq 33$ & $\begin{array}{c}\text { Sangat } \\
\text { Relevan/ } \\
\text { Sangat Baik }\end{array}$ & 53 & 70,7 \\
\hline \multicolumn{2}{|c|}{ Jumlah } & 75 & 100 \\
\hline
\end{tabular}

Penyajian data pada tabel 12 dalam bentuk diagram lingkaran dapat dilihat pada gambar 10.

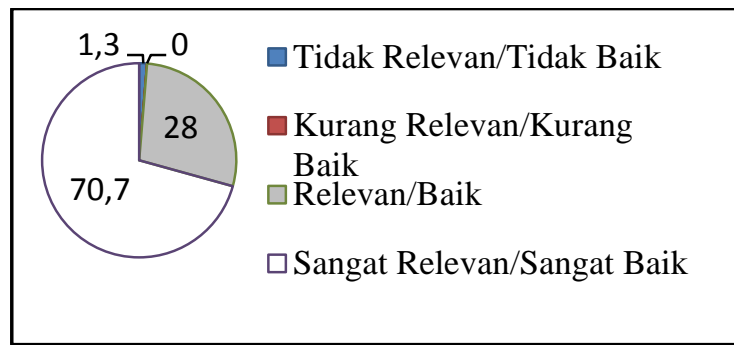

Gambar 10. Diagram Lingkaran Pendapat Siswa terhadap Aspek Proses

Secara umum, mengacu pada pemaparan di atas, dapat disimpulkan bahwa pendapat siswa terhadap aspek produk prakerin termasuk dalam kategori sangat relevan/sangat baik. Menurut siswa, program prakerin memberikan kemanfaatan yang sangat baik bagi siswa dan sangat relevan dengan kebutuhan siswa.

Menurut pendapat instruktur, berdasarkan hasil pengolahan data diperoleh nilai Rerata sebesar 15,40; median sebesar 15,00; modus sebesar 13; standar deviasi sebesar 2,30; nilai minimum sebesar 13 dan nilai maksimum sebesar 19. Distribusi frekuensi dan persentase data disajikan pada tabel 13 .

Tabel 13. Kategori Pendapat Instruktur terhadap Aspek Produk

\begin{tabular}{|c|c|c|c|}
\hline Interval Nilai & Kategori & Frek & $\begin{array}{c}\text { Frek. } \\
\text { Relatif }(\%)\end{array}$ \\
\hline$X<10$ & $\begin{array}{c}\text { Tidak } \\
\text { Relevan/ } \\
\text { Tidak Baik }\end{array}$ & 0 & 0 \\
\hline $10 \leq X<12,5$ & $\begin{array}{c}\text { Kurang } \\
\text { Relevan/ } \\
\text { Kurang Baik }\end{array}$ & 0 & 0 \\
\hline $12,5 \leq \mathrm{X}<15$ & $\begin{array}{c}\text { Relevan/ } \\
\text { Baik }\end{array}$ & 2 & 40 \\
\hline$X \geq 15$ & $\begin{array}{c}\text { Sangat } \\
\text { Relevan/ } \\
\text { Sangat Baik }\end{array}$ & 3 & 60 \\
\hline \multicolumn{2}{|c|}{ Jumlah } & 5 & 100 \\
\hline
\end{tabular}

Penyajian data pada tabel 13 dalam bentuk diagram lingkaran pada Gambar 11. 


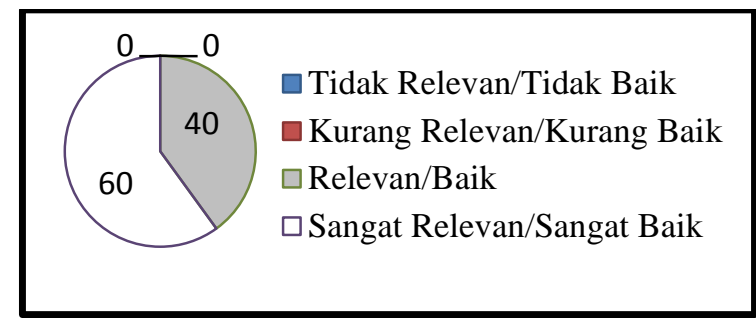

Gambar 11. Diagram Lingkaran Pendapat Instruktur terhadap Aspek Produk

Secara umum dengan mengacu pada pemaparan di atas, dapat disimpulkan bahwa pendapat instruktur prakerin terhadap aspek produk termasuk dalam kategori sangat relevan/sangat baik. Menurut instruktur, program prakerin memiliki manfaat yang sangat baik bagi DUDI dan siswa serta sangat relevan dengan kebutuhan DUDI dan siswa.

\section{SIMPULAN DAN SARAN}

\section{Simpulan}

Berdasarkan pengumpulan data dan hasil analisis data, dapat ditarik kesimpulan bahwa evaluasi aspek konteks program prakerin berdasarkan responden guru, siswa, dan instruktur termasuk dalam kategori sangat relevan/sangat baik; evaluasi aspek input program prakerin berdasarkan responden guru dan siswa termasuk dalam kategori kurang relevan/kurang baik, dan berdasarkan responden instruktur masuk dalam kategori relevan/ baik; evaluasi aspek proses program prakerin berdasarkan responden guru dan instruktur masuk dalam kategori sangat relevan/sangat baik; berdasarkan responden siswa masuk dalam kategori relevan/baik; evaluasi aspek produk program prakerin berdasarkan responden guru, siswa dan instruktur termasuk dalam kategori sangat relevan/sangat baik.

Selain kesimpulan tersebut, dalam penelitian ini juga terdapat temuan yaitu belum mengikutsertakan DUDI dalam proses perencanaan sehingga kesesuaian dengan kebutuhan DUDI belum terukur dengan baik; kesesuaian sarana (peralatan praktik) jumlahnya masih terbatas dan belum sesuai dengan kebutuhan DUDI; peralatan di DUDI kurang sesuai dengan kebutuhan; program prakerin belum sesuai dengan hasil pembelajaran yang diperoleh siswa; program sekolah tidak sepenuhnya sesuai dengan DUDI, sehingga DUDI menyesuaikan dengan kondisi yang ada. Dalam hal peralatan, masih perlu menyesuaikan dengan perkembangan teknologi mutakhir; sekolah tidak memiliki panduan prakerin, pembekalan hanya dilakukan seminggu sebelum pelaksanaan dengan materi dominan motivasi, pengarahan termasuk dalam pembekalan dan diberikan klasikal oleh kepala sekolah, guru BK, dan ketua kompetensi keahlian sehingga dari aspek kesiapan belum baik; instruktur tidak mendapatkan buku panduan prakerin sehingga kesiapan materi kurang baik; mekanisme penilaian unjuk kerja di DUDI hanya dilakukan di akhir program tidak di setiap penyelesaian standar kompetensi; monitoring guru ke DUDI sangat minim; kurangnya waktu istirahat; kurangnya variasi jenis pekerjaan yang dilakukan; hasil pembelajaran di DUDI belum dapat meningkatkan keterampilan siswa karena tidak semua kompetensi diberikan pada saat prakerin, disesuaikan dengan kondisi dan aturan yang berlaku di DUDI; bukti prakerin siswa berupa sertifikat tidak semua DUDI bersedia memberikan kepada siswa, sehingga sertifikat ada yang dibuatkan oleh sekolah berdasarkan pelimpahan wewenang dari DUDI. Hal ini menunjukkan bahwa DUDI belum sepenuhnya memberikan apresiasi terhadap kinerja siswa selama prakerin.

\section{Saran}

Mengacu pada hasil penelitian yang telah dilakukan, dapat diberikan saran-saran yaitu bagi pengelola prakerin dalam hal ini adalah sekolah agar lebih meningkatkan manajemen pengelolaan prakerin dan melibatkan pihak-pihak yang terkait baik guru, siswa maupun DUDI dalam merencanakan prakerin agar terjadi keterpaduan antara apa yang diharapkan sekolah dengan hasil yang diperoleh siswa di DUDI. Keterlibatan siswa dapat ditempuh dengan cara menambah intensitas pemberian pengetahuan kepada siswa mengenai prakerin agar siswa memiliki pengetahuan yang komprehensif tentang prakerin, merasa memiliki dan menjadi bagian dari program prakerin serta mengetahui kemanfaatan prakerin; sekolah juga diharapkan dapat melakukan control/pengawasan yang baik terhadap pelaksanaan prakerin. Pengawasan sekolah dapat dilakukan dengan membentuk tim monitoring untuk mengunjungi siswa di DUDI secara insidental dan mengecek monitoring yang dilakukan guru pem- 
bimbing terhadap siswa yang dibimbingnya; bagi DUDI/mitra prakerin dapat memberikan kesempatan kepada siswa untuk menguasai kompetensi sesuai yang dipersyaratkan oleh sekolah agat terjadi sinergitas antara kompetensi yang dipersyaratkan dengan kompetensi yang diperoleh siswa saat pelaksanaan prakerin.

\section{DAFTAR PUSTAKA}

(2007). Spektrum bidang dan kompetensi keahlian sekolah menengah kejuruan. Jakarta: Direktorat Pembinaan SMK.

(1995). Keterampilan menjelang 2020 untuk era global. Jakarta: Depdikbud.

(2006). Penyelenggaraan sekolah menengah kejuruan bertaraf internasional. Jakarta: Dikmenjur Dirjen Mandikdasmen Depdiknas.

Arfandi, Anas. (2009). "Evaluasi pelaksanaan praktek kerja industri siswa SMK kompetensi keahlian teknik bangunan di Kota Makassar". Tesis tidak diterbitkan. Pascasarjana-UNY.

Azwar, S. (2012). Penyusunan Skala Psikologi. Yogyakarta: Pustaka Pelajar.

Ditpsmk. (2008). Data pokok SMK versi 2.0 beta. Diambil pada tanggal 25 Agustus 2009, dari http://datapokok.ditpsmk. net/index.php?nama $=\&$ prop $=04 \& \mathrm{kab}=$ 0402\&smk.

Djojonegoro, Wardiman. (1998). Pengembangan sumberdaya manusia melalui sekolah menengah kejuruan (SMK). Jakarta: PT Jayakarta Agung Offset.

Lampiran keputusan direktur jenderal manajemen pendidikan dasar dan menengah nomor 251/C/KEP/MN/2008 tentang spektrum keahlian pendidikan menengah kejuruan.

Nahriana. (2009). Identifikasi masalah dalam pelaksanaan pendidikan keberlanjutan di pendidikan kejuruan. HomeEC (Jurnal Teknologi Kerumahtanggaan). Vol. 7 No. 1 Februari, Abstrak. Diambil pada tanggal 12 Oktober 2012, dari http:jurnal HomeC/IDENTIFIKASI\% 20MASALAH\%20DALAM\%20PELA KSANAAN\%20PENDIDIKAN\%20KE BERLANJUTAN\%20DI\%20PENDIDI KAN\%20KEJURUAN\%20\%20\%20Na hriana\%20\%20\%20HomeEC\%20\%28J urnal\%20Teknologi\%20Kerumahtangg aan\%29.htm

Soenaryo, dkk. (2002). Sejarah pendidikan teknik kejuruan di Indonesia, membangun manusia produktif. Jakarta: Direktorat Dikmenjur.

Tamrin, A. G. (2008). Pendidikan sistem ganda pada sekolah menengah kejuruan. Jurnal Ilmiah Pendidikan Teknik dan Kejuruan. Volume 1 Nomor1, 48-49.

Yuli. (2012). Evaluasi pelaksanaan praktek kerja industri siswa SMK kompetensi keahlian penyuluhan pertanian di Kalimantan Selatan. Tesis magister, tidak diterbitkan, Universitas Negeri Yogyakarta, Yogyakarta. 